\title{
Model Pengembangan Kurikulum Mata Kuliah Pengembangan Kepribadian dalam Merespon Era Informasi Digital
}

\author{
Mohammad Karim \\ Universitas Islam Negeri Maulana Malik Ibrahim Malang, Indonesia \\ mohammadkarim@uin-malang.ac.id
}

\begin{abstract}
University graduates are expected to be individuals who deserve to be emulated. Their way of thinking, behaving and spiritual mentality become an example in society. But that is not always the case. There is a phenomenon that highly educated people are easily influenced by false information. Thus, there are some questions the college curriculum in preparing graduates with good character. This research aims to find the formulation of the ideal model for curriculum development in Personality Development Courses in tertiary institutions. This research paradigm is interpretive. The research approach is qualitative. The type of research is Multi Site-Study. Collecting data in methods participation, observation, documentation and interviews. Data analysis in the form of categorization, meaning, comparison and generalization. The data validity test was triangulation. The data presentation is descriptive. This study reports that the curriculum development model for Personality Development Subjects can be done by first identifying graduate performance and user responses. Then compile graduate profiles, teaching materials, process standards and evaluation.
\end{abstract}

Keywords. Curriculum; Personality Development Subject.

\begin{abstract}
Abstrak. Lulusan universitas diharapkan menjadi pribadi yang pantas ditiru. Cara berfikir, bersikap dan mental spritualnya menjadi contoh di tengah-tengah masyarakat. Tetapi faktanya tidak selalu demikian. Ada fenomena orang-orang berpendidikan tinggi mudah terpengaruh oleh informasi palsu. Sehingga, ada beberapa kalangan mempertanyakan kurikulum perguruan tinggi dalam menyiapkan lulusan yang berkarkter baik. Penelitian bertujuan untuk menemukan rumusan model ideal pengembangan kurikulum Mata Kuliah Pengembangan Kepribadian di perguruan tinggi. Paradigma penelitian ini adalah interpretif. Pendekatan penelitiannya adalah kualitatif. Jenis penelitiannya adalah Studi Multi Situs. Metode pengumpulan datanya berupa partisipasi, observasi, dokumentasi dan wawancara. Analisis data berupa kategorisasi, pemaknaan, komparasi dan generalisasi. Uji validitas data berupa trianggulasi. Penyajian data bersifat deskriptif. Penelitian ini melaporkan bahwa model pengembangan kurikulum Mata Kuliah Pengembangan Kepribadian dapat dilakukan dengan langkah awal mengidentifikasi performance lulusan dan tanggapan pengguna lulusan terlebih dahulu. Kemudian menyusun profil lulusan, bahan ajar, standar proses dan evaluasi.
\end{abstract}

Kata kunci. Kurikulum; Mata Kuliah Pengembangan Kepribadian 


\section{A. PENDAHULUAN}

Selama ini, pengembangan kurikulum banyak dilakukan dengan model yang berbasis pada revolusi industri 3.0, belum banyak model pengembangan kurikulum yang berbasis pada permasalahan revolusi industri 4.0. Terlebih, yang spesifik membahas kurikulum pendidikan karakter dalam bentuk mata kuliah pengembangan kepribadian (MPK). Tulisan ini ingin memperkaya studi yang belum banyak dimaksud.

Orang yang berpindidikan tinggi, diharapkan menjadi pribadi yang pantas ditiru. Cara berfikir, bersikap dan mental spritualnya menjadi contoh di tengah-tengah masyarakat, tetapi faktanya tidak selalu demikian. Ada fenomena orang-orang berpendidikan tinggi mudah terpengaruh oleh informasi digital yang palsu atau hoax (Republika.com, 2017). Mereka terlibat aktif membagikan informasi tersebut. Bahkan, ada sebagian mereka terlibat ujaran kebencian dan tindakan terorisme. Seakan, tradisi berfikir kritis terhadap segala informasi sudah hilang pada diri mereka. Ada dosen yang terlibat dalam ujaran kebencian dan penyebaran berita palsu (Detik.com, 2019). Tak terkecuali mahasiswa yang juga menjadi bagian dari penyebaran informasi palsu(liputan6.com, 2019). Ada juga oknum Guru yang ikut membuat berita palsu(news.detik.com, 2019). Tak jarang pula, orang tua terlibat aktif dalam penyebaran berita palsu(tirto.id, 2019).Data Kemenkominfo menyebutkan bahwa ada sekitar 800.000 situs di Indonesia yang telah terindikasi sebagai penyebar informasi palsu (Republika.com, 2017). Keterlibatan lulusan perguruan tinggi dalam berbagai perkara hukummerupakan ancaman bagi sumber daya manusia Indonesia ke depan. Fenomena tersebut merupakan suatu krisis moral yang berbahaya (Aqil, 2019).

Akhir-akhir ini, pentingnya pendidikan karakter begitu didengung-dengungkan. Hal ini sebagai respon terhadap turunnya kualitas moral anak bangsa. Umumnya, solusi yang ditawarkan untuk meningkatkan moralitas anak bangsa adalah melalui pendidikan, khususnya pendidikan karakter atau pengembangan kepribadian. Maka, penting adanya Mata Kuliah Pengembangan Karakter (MPK)- jika pada tingkat universitas.

Universitas merupakan lembaga pendidikan tertinggi untuk melahirkan manusiamanusia yang berakarakter baik. Maka, dibutuhkan gambaran model pengembangan kurikulum mata kuliah pengembangan kepribadian. Sehingga, bisa menjadi contoh kepada lembaga pendidikan yang lain. Pendidikan tak boleh jalan di tempat. Ia harus selalu relevan dengan tantangan zaman. Pendidikan haruslah sensisitif dengan perubahan. Pendidikan harus terus menerus dikembangkan. Dalam pendidikan ada kurikulum. Dalam kurikulum ada tujuan belajar, bahan ajar, metode belajar, dan evaluasi belajar. Maka, penting untuk terus-menerus mengembangkan kurikulum.

Intinya, ada banyak perubahan perilaku akibat informasi digital yang seperti air bah. Informasi digital menemukan momentumnya dengan munculnya istilah "Industri 0.4". Pada Hannover Fair pada tahun 2011, mucul istilah "Industri 0.4". Kemudian, pada Hannover Fair, tanggal 8 April 2013 Kelompok Kerja 0.4 memaparkan istilah 0.4 secara lebih rinci. Istilah ini mengacu pada tahap perkembangan revolusi industri yang kini mencapai tahap ke-4, yang didahului oleh 3 tahap sebelumnya. Tahap ke-1 adalah tahap mekanisasi produksi dengan kekuatan air dan mesin uap. Tahap ke-2 adalah tahap produksi massal, penerapan rantai produksi, dan penggunaan tenga listrik. Tahap ke-3 adalah tahap penggunaan komputer dan otomatisasi. Tahap-4 adalah adalah tahap perkembangan teknologi informasi digital, yang melahirkan interkoneksitas vertikal dan horizontal di dalam satu organisasi, antar-organisasi, antar-wilayah, dan antar-benua, dengan tidak mengenal batas waktu dalam aliran informasi dan pengambilan keputusan (Puncreobutr, 2016; Sidik, Awang, \& Ahmad, 2019; Zulkifli, Hussain, Wahid, 2019).

Sejauh ini, literatur atau studi yang membahas pengembangan kurikulum terperangkap pada satu kecenderungan yaitu hanya membicarakan pengembangan 
Mohammad Karim: Model Pengembangan Kurikulum...

kurikulum secara umum, dan kurang memperhatikan tentang kepribadian dan karakter. Memfokuskan studi hanya pada pengembangan kurikulum secara umum dan hanya pada mata kuliah keahlian sebagai objek akan membawa resiko pada pengabaian pendidikan karakter, sikap dan spritual. Karakter dan perilaku kreatif misalnya, merupakan sesuatu yang perlu dibentuk. Namun demikian, kreativitas sebagai bagian dari karekter penting yang dimiliki lulusan perguruan tinggi cenderung kurang mendapat perhatian dalam proses pengembangan kurikulum, sebagai perilaku yang dirancang sejak awal bahkan saat mereka sudah menjadi lulusan.

Salah satu studi menyebutkan bahwa salah satu faktor penyebab adanya lulusan perguruan tinggi yang punya sikap mental kurang baik adalah keberadaan Mata Kuliah Pengembangan Kepribadian (MPK) yang dianggap sampingan, kurang mendapat perhatian dan dianggap kurang begitu penting (Sugihartono, 2013). Hal ini diperkuat hasil pengamatan penulis selama mengampu Mata Kuliah Pengembangan Kepribadian (MPK).

Berdasar diskripsi di atas, maka penting diteliti bagaimanakah Model Ideal Pengembangan Kurikulum di Perguruan Tinggi, yang dalam penelitian ini diwakili oleh dua universitas, yaitu Universitas Islam Negeri Maulana Malik Ibrahim Malang dan Universitas Islam Malang. Merumuskan model pengembangan kurikulum MPK dalam studi ini berpijak pada tahapan pengembangan kurikulum di dua universitas tersebut.

\section{B. METODE PENELITIAN}

Paradigma penelitian ini adalah interpretif. Pendekatan penelitiannya adalah kualitatif. Adapaun jenis penelitiannya adalah Studi Multi Situs. Studi multi-situs digunakan untuk meneliti sebuah kasus di lebih dari satu tempat. Adapun Metode pengumpulan datanya berupa partisipasi, observasi, dokumentasi dan wawancara. Analisis data berupa kategorisasi, pemaknaan, komparasi dan generalisasi. Uji validitas data berupa trianggulasi. Penyajian data bersifat deskriptif.

\section{HASIL DAN PEMBAHASAN}

Pengembangan kurikulum Mata Kuliah Pengembangan Kepribadian (MPK) di Universitas Islam Negeri Maulana Malik Ibrahim Malang dilakukan oleh tim yang dibentuk oleh Rektor, dan berkaitan langsung dengan tugas Wakil Rektor Bidang Akademik. Tim tersebut dikoordinatori Lembaga Penjaminan Mutu. Ada workshop khusus yang membahas tentang Pengembangan kurikulum Mata Kuliah Pengembangan Kepribadian (MPK), juga ada workshop kurikulum secara umum dan tingkat universitas, yang di dalamnya MPK juga turut dibahas.

Adapun Pengembangan kurikulum di Universitas Islam Malang dilakukan oleh tim kecil yang dibentuk di tingkat Prodi dan Fakultas. Kemudian, dokumen kurikulum yang dihasil oleh tim tersebut diseleraskan dengan format Kerangka Kualifikasi Nasional Indonesia (KKNI). Tidak ada workshop khusus yang membahas tentang Pengembangan kurikulum Mata Kuliah Pengembangan Kepribadian (MPK). Pengembangan kurikulum Mata Kuliah Pengembangan Kepribadian (MPK) dimasukkan dalam kegiatan pengembangan kurikulum secara umum.

Universitas Islam Negeri Maulana Malik Ibrahim Malang hanya mengandalkan pandangan dari pandangan pengguna lulusan dalam melakukan Tracer Study. Adapun Universitas Islam Malang sudah memakai pandangan pengguna lulusan dan dari lulusan sendiri itu sendiri. Sehingga, peran aktif alumni untuk memberikan masukan kepada Program Studi sangat menentukan pengembangan kurikulum. Setiap Program Studi sudah memasang menu untuk kegiatan Tracer Study di website masing-masing. Tracer Study dilakukan secara daring sebab lebih simpel. Organisasi persatuan alumni menjadikan hal ini sebagai program utama mereka, agar jaringan alumni dapat berkontribusi dalam ikut 
serta mengembangkan universitas yang menjadi almamater. Tentu saja, oraganisasi alumni menjadi lebih hidup dan lebih diperhitungkan keberadaannya dalam struktur kelembagaan di universitas.

Adapun model pengembangan kurikulum pada dua universitas ini terlebih pada Mata Kuliah Pengembangan Kepribadian (MPK) atau disebut juga Mata Kuliah Universitas (MKU) juga diawali dengan mengidentifikasi karakter apa saja yang harus dimiliki lulusan. Langkan identifikasi diawali dengan melakukan tracer study, yaitu para lulusan diminta untuk mengisi isian yang di dalamnya menggambarkan karakter apa saja yang dibutuhkan di tempat kerja. Selain itu, para pengguna lulusan juga diminta pandangan dengan menuliskannya pada isian tentang karakter apa saja yang harus dimiliki oleh lulusan dan dibutuhkan oleh tempat kerja, sehingga para lulusan berkontribusi maksimal kepada penyesaian masalah di tempat kerja dan masyarakat pada umumnya.

Hasil tracer study tersebut kemudian dikombinasikan dengan masukan para pakar dan perundangan yang berlaku. Berdasar hasil tacer study, masukan pakar dan perundangan kemudian dibuatlah pola penyusunan kurikulum dalam bentuk template. Template memuat empat komponen kurikulum, yaitu 1. Profil lulusan, 2. Bahan ajar, 3. Proses dan 4, evaluasi.

Setelah komponen kurikulum tersusun lengkap dalam satu dokumen, maka para penyusun akan mempresentasikan di depan pakar dan kolega sehingga ada penyempurnaan dan diakhiri pengesahan. Setelah pengesahan, maka diimplementasikan. Empat tahun kemudian dievaluasi kembali dalam bentuk workshop pengembangan kurikulum. Artinya, proses pengembangan kurikulum, ada (1) perencanaan, (2) penyusunan, (3) implementasi dan (4), evaluasi.

\section{a. Tahapan Pengembangan Kurikulum MPK}

Model pengembangan kurikulum MPK yang dilakukan oleh UIN Maulana Malik Ibrahim Malang adalah: Pertama, identifikasi dan analisis kebutuhan kebutuhan pengguna lulusan. Kegiatan ini berupa: 1, Identifikasi dan analisis kebutuhan dan harapan pengguna lulusan, 2. Identifikasi dan analisis yang dibutuhkan di masa mendatang, 3. Identifikasi dan analisis tantangan peluang, dan ancaman masa mendatang. Kegiatan ini penting karena dari situlah lembaga pendidikan dapat mengetahui problem lulusan dan pengguna lulusan dan berusaha untuk mengadakan perbaikan untuk lulusan selanjutnya. Inilah langkah penting dalam rangka mengembangkan kurikulum MPK. Jika hal ini dipertajam maka MPK bisa menjadi jaminan untuk melahirkan lulusan yang tidak mudah percaya informasi palsu sebab memliki nalar kritis, lulusan yang tidak menganggur sebab sikap kreatif, lulusan bermanfaat sebab karakter suka membantu, dan seterusnya (Bidshahri, 2017; Kelley, Knowles, Han, \& ..., 2019).

Kedua, merumuskan profil lulusan dan standar kompetensi. Kegiatan ini dapat didefinisikan sebagai kegiatan penyusunan peran yang dapat dilakukan oleh lulusan di bidang keahlian atau bidang kerja tertentu setelah menyelesaikan program studi. Diskripsi yang jelas dan terukur tentang peran lulusan ini penting karena akan mempermudah penyusunan komponen kurikulum berikutnya. Profil lulusan akan menjadi tujuan utama. Profil lulusan bagaikan hulu dan hilir. Awal pijakan menyusun komponen kurikulum, juga menjadi tujuan akhir dari penyusunan komponen kurikulum. Mahasiswa juga terlibat dalam penyusunan profil lulusan melalui suvei dan wawancara (Syarif, 2017).

Ketiga, menyusun bahan ajar. Kegiatan ini berupa penentuan daftar materi dan kegiatan yang bisa dilakukan oleh mahasiswa agar mereka mencapai profil lulusan. Bentuk bahan ajar bisa berupa cetak, seperti handout, buku, modul, lembar kerja siswa, brosur, leaflet, walchat. Bisa berupa audio seperti radio, kaset, CD audio. Bisa berupa visual seperti foto, gambar, model/maket. Bisa berupa multimedia seperti CD interktif, internet, sosmed, 
youtube, e-learning. Ciri bahan ajar yang baik adalah 1. menimbulkan minat baca, 2 . disusun berdasarkan pola belajar yang fleksibel, 3. struktur berdasarkan kebutuhan siswa, 4. memberi kesempatan pada siswa untuk berlatih, 5. mengakomodasi kesulitan belajar siswa, 6. memberikan rangkuman, 7. gaya penulisan komunikatif, 8. kepadatan berdasar kebutuhan mahasiswa, 7. dikemas untuk proses instruksional (Maimun, 2016). Damayanti menuliskan (1) menyajikan petunjuk atau kegiatan pembelajaran yang jelas; (2) menyajikan materi yang sesuai dengan kebutuhan mahasiswa; (3) menyajikan contohcontoh yang memudahkan mahasiswa dalam memahami materi yang disajikan; (4) menyajikan latar yang berwarna untuk bagian contoh dan rangkuman serta glosarium, dan; (5) menyajikan komponen buku teks yang terdiri dari judul, standar kompetensi (SD), tujuan pembelajaran, materi, latihan, petunjuk jawaban latihan, rangkuman, tes formatif, patokan penilaian, kunci jawaban, dan daftar pustaka (Damayanti, Nurhayati, \& Subadiyono, 2018). Adanya bahan ajar sangatlah penting, karena ia pedoman bagi dosen dan mahasiswa untuk mencapai kompetensi tertentu (Widya, 2020).

Keempat, presentasi dan revisi dokumen. Presentasi adalah menjelaskan konsep kurikulum secara detail kepada tim dan pakar kurikulum(kbbi.kemdikbud.go.id, 2020). Revisi adalah peninjauan (pemeriksaan) kembali untuk perbaikan(kbbi.kemdikbud.go.id, 2020). Presentasi berfungsi untuk memaparkan konsep agar mendapatkan masukan dan perbaikan. Proses perbaikan setelah presentasi itulah disebut revisi.

Kelima, penyerahan dokumen. Penyerahan adalaah kegiatan menyetorkan dokumen kurikulum yang sudah direvisi. Penyerahan dokumen kepada panitia workshop adalah penting, karena dokumen kurikulum merupakan produk workshop. Dokumen itu merupakan bukti konkrit bahwa ada kegiatan workshop yang telah menggunakan uang negara. Sehingga, dapat dipertanggung jawabkan.

Keenam, reduksi dokumen. Reduksi dokumen adalah kegiatan seleksi dan penentuan dokumen bahan ajar yang benar-benar layak untuk dicetak dan diterbitkan. Kegiatan ini penting karena bahan ajar ini akan dibaca oleh mahasiswa dan masyarakat umum. Selain mengikuti standar akademik ketak, juga mengikuti standar market. Hal ini juga sesuai dengan standar yang berlaku di UIN Maliki Press sebagai penerbit.

Ketujuh, editing dan layouting. Editing adalah proses menata dan memberbaiki naskah agar enak dibaca, pesan isi tersampaikan dan sesuai gaya sekingkung penerbitan. Secara umum, pekerjaan editing adalah berkaitan dengan proses sebelum cetak(Trim, 2017). Layouting adalah Layout adalah penyusunan dari elemen-elemen desain yang berhubungan kedalam sebuah bidang sehingga membentuk susunan artistik. Hal ini bisa juga disebut manajemen bentuk dan bidang. Tujuan utama layout adalah menampilkan elemen gambar dan teks agar menjadi komunikatif dalam sebuah cara yang dapat memudahkan pembaca menerima informasi yang disajikan(Silaen, 2020).

Kedelapan, mencetak dan mendistrubusikan. Mencetak adalah Membuat tulisan atau gambar dari klise pada kertas dengan melumas klise itu dengan tinta lalu ditekankan pada kertas (kbbi.kemdikbud.go.id, 2020). Distrubusi adalah Penyaluran (pembagian, pengiriman) kepada beberapa orang atau ke beberapa tempat(kbbi.kemdikbud.go.id, 2020). Kegiatan ini penting karena kegiatan inilah yang akan benar-benar mewujudkan karya menjadi kenyataan berupa buku ajar. Adapun manfaat distrubusi adalah mendekatkan akses bahan ajar kepada mahasiswa dan manyarakat umum. Sehingga, manfaatnya lebih jelas terasa oleh mereka.

Adapun Universitas Islam Malang dalam mengembangkan kurikulum MPK dengan tahapan berikut: Pertama, tracer study. kegiatandapat didefinisikan sebagai kegiatanmelakukan penelusuran penyerapan, proses, dan posisi lulusan di dunia kerja. Atau masa tunggu lulusan sampai punya pekerjaan (Fajaryati et al., 2015). Kegiatan ini penting karena hasil tracer study dijadikan dasar pengembangan kurikulum, 
pengembangan proses pembelajaran, dan peningkatan layanan karir untuk mempersiapkan lulusan siap bersaing di dunia kerja dan menciptakan lapangan kerja secara mandiri.

Kedua, menyusun profil lulusan. Tidak ada kurikulum tanpa profil lulusan (Hakim, Tobroni, Ishomuddin, \& Khozin, 2020). Kegiatan ini dapat didefinisikan sebagai kegiatan penyusunan peran yang dapat dilakukan oleh lulusan di bidang keahlian atau bidang kerja tertentu setelah menyelesaikan program studi. Diskripsi yang jelas dan terukur tentang peran lulusan ini penting karena akan mempermudah penyusunan komponen kurikulum berikutnya. Profil lulusan akan menjadi tujuan utama. Profil lulusan bagaikan hulu dan hilir. Awal pijakan menyusun komponen kurikulum, juga menjadi tujuan akhir dari penyusunan komponen kurikulum.

Ketiga, menentukan bahan ajar.Kegiatan ini berupa penentuan daftar materi dan kegiatan yang bisa dilakukan oleh mahasiswa agar mereka mencapai profil lulusan. Bentuk bahan ajar bisa berupa cetak, seperti handout, buku, modul, lembar kerja siswa, brosur, leaflet, walchat. Bisa berupa audio seperti radio, kaset, $C D$ audio. Bisa berupa visual seperti foto, gambar, model/maket. Bisa berupa multimedia seperti CD interktif, internet, sosmed, youtube, e-learning (Arsanti, 2018). Adanya bahan ajar sangatlah penting, karena ia pedoman bagi dosen dan mahasiswa untuk mencapai kompetensi tertentu.

Keempat, presentasi dokumen kurikulum.Presentasi adalah menjelaskan konsep kurikulum secara detail kepada tim dan pakar kurikulum(kbbi.kemdikbud.go.id, 2020). Presentasi berfungsi untuk memaparkan konsep agar mendapatkan masukan dan perbaikan. Proses perbaikan setelah presentasi itulah disebut revisi.

Kelima, penyerahan dan pengesahan dokumen. Penyerahan adalah kegiatan menyetorkan dokumen kurikulum yang sudah direvisi. Penyerahan dokumen kepada panitia workshop adalah penting, karena dokumen kurikulum merupakan produk workshop. Dokumen itu merupakan bukti konkrit bahwa ada kegiatan workshop yang telah menggunakan uang negara. Sehingga, dapat dipertanggung jawabkan. Pengesahan adalah perbuatan mengesahkan; pengakuan berdasarkan hukum; peresmian(kbbi.kemdikbud.go.id, 2020). Pengesahan berfungsi sebagai tanda bahwa dokumen tersebut resmi berlaku di lembaga.

Keenam, Sosialisasi dan mengunggah dokumen. Sosialisasi dapat didefinisikan sebagai kegiatan distribusi dokumen yang sudah disahkan secara kelembagaan kepada para pengguna. Kegiatan ini penting karena akan mendekatkan akses para pengguna dan menjadi pemahaman bersama seluruh sivitas akademika. Mengunggah adalah memberi berkas ke layanan informasi daring atau ke komputer lain dari komputer yang digunakan (kbbi.kemdikbud.go.id, 2020).

\section{b. Model Pengembangan Kurikulum MPK}

Model adalah tiruan. Atau, replika dari bentukdan proses sebenarnya. Model berfungsi untuk memberikan gambaran konkrit tentang benda dan proses sebenarnya.Model pengembangankurikulum memuat ide atau gagasan, tatacara pelaksanaan dan evaluasihasil akhir (Solehah, Rafi Fatkhi, \& Dhiyah, 2020), lihat juga (Dahlan, Budiwat, \& Kurniawati, 2013). Model merupakan petunjuk perancanaan untuk kegiatan pengelolaan(Sanjaya W, 2008). Model adalah keseluruhan proses (Arifn, 2012). Pengembangan kurikulum dapat didefinisikan sebagai kegiatan mengembangkan komponen-komponen kurikulum agar lebih efektif membantu anak didik mencapai tujuan pendidikan (Firmansyah, 2020, Siswanto \& Susanti, 2019)

Berdasar tahapan yang dilakukan oleh dua perguruan tinggi yang menjadi objek penelitian ini, maka model ideal pengembangan kurikulum ideal MPK perguruan tinggi dapat dituliskan sebagai berikut:Pertama, adanya kejelasan kurikulum yang akan 
dihasilkan. Pimpinan dan tim pengembang kurikulum mempunyai kejelasan konsep kurikulum yang akan dihasilkan. Kejelasan konsep adalah tergambarnya secara nayata dan terukur kurikulum yang akan dikembangkan. Kejelasan konsep ini penting, sebab bisa memberikan panduan pada benarnya keputusan yang akan diambil pimpinan dan benarnya tahapan yang akan dilakukan oleh tim pengembang kurikulum. Jika dalam mengembangkan kurikulum, konsep kurikulum yang dihasilkan nantinya tidak jelas, maka kebijakan dan tahapan yang dilakukan tidak akan tepat dan benar. Pekerjaan tidak akan efektif dan efisien. Dan, akhirnya terjadi kegagalan, sebab tak sesuai harapan.

Kedua, penajaman konsep. Penajaman konsep merupakan kegiatan untuk memperjelas komponen dan format kurikulum yang akan disusun. Penajaman konsep kurikulum yang akan dihasilkan dapat dilakukan melalui workshop. Dalam workshop ada kuliah dari pakar kurikulum yang akan memberikan arahan secara konseptual. Kegiatan ini penting untuk memberikan jaminan agar kurikulum yang disusun benar.

Ketiga, memformat kurikulum yang akan dihasilkan dalam bentuk template. Template adalahSebuah dokumen atau file yang memiliki format preset, digunakan sebagai titik awal untuk aplikasi tertentu sehingga format tidak harus diciptakan kembali setiap kali digunakan. Template berfungsi sebagai haluan dan panduan bagi peserta workshop, sehingga para peserta tinggal mengikuti template untuk mengembangkan kurikulum. Template ini dibuat berdasar hasil dari tahapan kejelasan konsep dan panajaman konsep. Template ini harus tersosialisasi kepada para peserta pengembangan kurikulum.

Keempat, menyusun profil lulusan. Profil lulusan adalah kegiatan penyusunan peran yang dapat dilakukan oleh lulusan di bidang keahlian atau bidang kerja tertentu setelah menyelesaikan program studi. Jika dalam mengembangkan kurikulum MPK sudah seleras dengan KKNI, maka penyusunan peran lulusan sudah dibuatkan templatenya. Diskripsi yang jelas dan terukur tentang peran lulusan ini penting karena akan mempermudah penyusunan komponen kurikulum berikutnya. Profil lulusan akan menjadi tujuan utama. Profil lulusan bagaikan hulu dan hilir. Awal pijakan menyusun komponen kurikulum, juga menjadi tujuan akhir dari penyusunan komponen kurikulum. Dalam menyusun profil lulusan diperlukan dasar. Salah satu dasarnya adalah hasil identifikasi dan analisis dari (a) Performance lulusan di dunia kerja/masyarakat, (b) Kondisi yang dihadapi lulusan, (c) Kritikan pengguna lulusan, (d) Harapan pengguna lulusan, (e) Aturan perundangan dan kebijakan pemerintah. Artinya, dalam menyusun profil lulusan dan standar kompetensi yang tersedia pada template berdasar pada hasil tracer study, yaitu hasil identifikasi dan analisis hal-hal tersebut di atas.

Sejumlah nilai yang dianggap layak untuk dijadikan sikap dari profil lulusan dan dikembangkan dalam Mata Kuliah Pengembangan Kepribadian (MPK) yakni nilai kabajikan religius, jujur, toleransi, disiplin, kerja keras, patriotisme, cinta damai, peduli lingkungan sosial, dan tanggung jawab(Mukhibat, 2020). Atau nilai-nilai dalam konteks olah pikir yang mengarah pada pengembangan kemampuan intelektual, olah hati yang mengarah pada kepekaan nurani, olah rasa yang mengarah pada ketajaman perasaan, serta olah raga yang mengarah pada ketangguhan dan daya juang(Sunarto \& Suhardiyanto, 2013).

Kelima, menyusun bahan ajar, proses dan evaluasi. Kegiatan merupakan kegiatan menentukan daftar materi dan progra pembelajran, media, guru, metode dan evaluasi dan akhirnya format raport atau Kartu Hasil Belajar (KHS) bahkan Surat Pendamping Ijazah (SKI). Penyusunan tiga komponen kurikulum tersebut (bahan ajar, proses dan evaluasi) dalam rangka mempermudah para mahasiswa untuk mudah mencapai profil lulusan. Artinya, penyusunan bahan ajar, proses dan evaluasi mengacu pada profil lulusan yang sudah tersusun. Bahan ajar, proses dan evaluasi menyesuaikan dengan keberadaan profil lulusan. 
Mahasiswa membutuhkan bahan ajar yang sesuai dengan kebutuhannya. Kebutuhan mahasiswa tersebut meliputi kebutuhan yang bersifat isi dan tampilan (cover). Bahan ajar dari segi isi, mahasiswa membutuhkan bahan ajar yang memiliki materi menarik, penyajian yang terinci, dan penggunaan bahasa yang mudah dipahami. Segi tampilan, mahasiswa mengharapkan bahan ajar yang menarik dari dan tampilan desain isi yang mampu memberikan daya tarik bagi mahasiswa(Damayanti et al., 2018).

Salah satu daftar MPK adalah Pembelajaran Pendidikan Kewarganegaraan (PPKN). Pembelajaran Pendidikan Kewarganegaraan di perguruan tinggi yang dimaksudkan untuk mencetak good citizen, yang didalamnya membelajarkan nilai-nilai dan norma yang berlaku kepada mahasiswa sehingga terbentuk karakter sadar hukum. Program pembelajaran PKn sudah sangat mendukung terhadap peningkatan kesadaran hukum mahasiswa (Belladonna, 2013).

Salah satu standar proses adalah menentukan proses belajar. MPK membutuhkan metode yang tepat. Proses pembelajaran yang menyentuh ranah kognitif, konatif, afektif, dan psikomotor secara proporsional, dapat memantapkan kepribadian mahasiswa.. Pada gilirannya dapat mewujudkan nilai-nilai dasar keagamaan, kenegaraan/ketatanegaraan, kebudayaan, kemasyarakatan, dan kebangsaan (Riyanto, 2009).

Keenam, presentasi dokumen kurikulum. Presentasi adalah menjelaskan konsep kurikulum secara detail kepada tim dan pakar kurikulum (kbbi.kemdikbud.go.id, 2020). Presentasi dimaksud dilakukan di depan pakar, tim workshop dan kolega. Kenapa hal ini diperlukan?. Sebab, sebuah kesimpulan ilmiah akan lebih valid, apabila mendapat komentar, kritikan dan akhirnya persetujuan serta pengakuan dari sesama akademisi atau ilmuwan. Kegiatan ini semacam uji validitas, uji ketepatan dan uji keilmiahan dokumen kurikulum yang sudah tersusun.

Ketujuh, revisi dan penyempurnaan. Revisi adalah peninjauan (pemeriksaan) kembali untuk perbaikan (kbbi.kemdikbud.go.id, 2020). Setelah ada komentar dan kritikan dari pakar, sesama kolega, dan panitia workshop, maka dilakukan revisi dokumen kurikulum. Proses ini bagaikan proses penyempurnaan dan finalisasi dokumen kurikulum yang sudah disusun sebelum disahkan secara kelembagaan.

Kedelapan, pengesahan dokumen kurikulum. Pengesahan adalah perbuatan mengesahkan; pengakuan berdasarkan hukum; peresmian (kbbi.kemdikbud.go.id, 2020). Sebelum pengesahan para peserta workshop diminta untuk mengumpkan dokumen kurikulum yang sudah direvisi sesuai masukan dari pakar, kolega dan tim workshop. Setelah itu, maka akan ada pengesahan kelembagaan bahwa dokumen kurikulum hasil workshop sudah resmi berlaku. Langkah selanjutnya adalah sosialisasi kepada seluruh sivitas akademika universitas tentang dokumen resmi dimaksud. Hari ini, proses sosialiasi dokumen kurikulum akan lebih efektif, jika soft file dokumen kurikulum juga diunggah di laman website lembaga yang memang bertugas menangani akademik dan kurikulum. Atau, juga bisa diunggah di laman website Program studi masing-masing. Kegiatan pengunggahan dokumen kurikulum semacam ini juga berfungsi sebagai dokumentasi. Jika kegiatan dokumentasi, pengesahan dan sosialisasi kurikulum selesai, maka selasailah kegiatan pengembangan kurikulum.

Idealnya, sebelum disahkan secara kelembagaan, kurikulum diujicoba terlebih dahulu, sehingga mencapi tingkat eror yang paling rendah. Hal ini dibenarkan oleh hasil penelitian Damayanti dan Subadiyono bahwa hasil penelitian tertentu dapat digunakan di perguruan tinggi lain yang memiliki karakteristik dan kebutuhan yang relatif sama dengan universitas tempat bahan ajar ini diujicobakan. Hal ini didasarkan pada hasil validasi ahli kelayakan isi/materi, ahli kebahasaan, ahli penyajian materi, dan ahli kegrafikan serta hasil uji coba lapangan terbatas (Damayanti et al., 2018). 
Mohammad Karim: Model Pengembangan Kurikulum...

Jika tahapan birokratis dan akademis untuk mengembangkan kurikulum MPK di Universitas Isllam Negeri Maulana Malik Ibrahim Malang dan Universitas Islam Malang diulustrasikan dalam satu peta konsep, maka dapat digambarkan model pengembangan kurikulum MPK sebagai berikut:

\section{Gambar 1. Peta Konesep model pengembangan kurikulum MPK}

1. Kejelasan konsep kurikulum yang akan dikembangkan dan dipahami oleh tim workshop
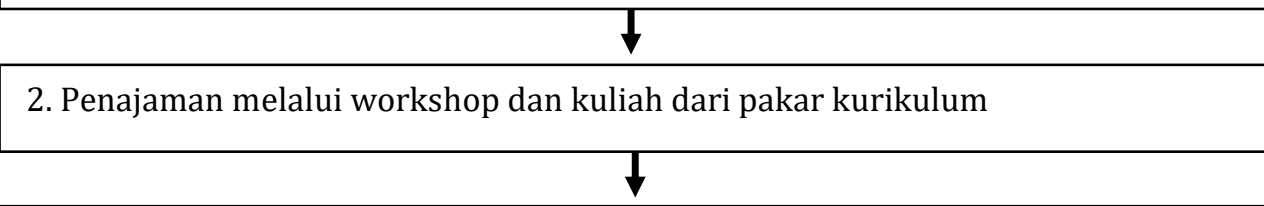

3. Membuat dan mensosialisasikan format atau template penyusunan kurikulum yang sesuai rekomendasi workshop

4. Menyusun profil lulusan dan standar kompetensi sesuai format atau template. Penyusunan profil lulusan berdasar pada hasil tracer study

5. Menetapkan bahan ajar, proses dan evaluasi yang mengacu pada profil lulusan dan sesuai template

6. Presentasi dokumen kurikulum di depan pakar, tim workshop dan kolega

\section{$\downarrow$}

7. Revisi dan penyempurnaan dokumen kurikulum sesuai masukan pakar, tim workshop dan kolega

8. Pengumpulan, pengesahan dan sosialisasi dokumen kurikulum baru

Jika temuan penelitian ini dipahami secara seksama, maka pengembangan kurikulum yang dilakukan oleh UIN Maulana Malik Ibrahim Malang dan Universitas Islam Malang lebih dekat dengan Model Tyler. Model Tyler didahului dengan analisis kebutuhan pengguna lulusan dan kebutuhan perserta didik. Bedanya dengan model yang dikembangkan oleh UIN Maulana Malik Ibrahim Malang dan Universitas Islam Malang adalah pada tahap implementasi. Model yang dikembangkan dua universitas ini mempunyai keunggulan pada sisi implementatif, sebab langkah-langkah dalam mengembangkan kurikulum sudah memperhatikan hal-hal yang terkecil, yang terhimpit, yang tak terduga sekalipun saat sebuah teori kurikulum dipraktikkan di lapangan. Bukankah secanggih apapun teori tanpa mampu memperhatikan hal-hal yang terselip di lapangan, maka teori itu tak akan terlaksana dan tak bisa terwujud. Model yang dikembangkan dua perguruan tinggi dimaksud-jika di teropong dengan teori Tyler, maka dapat dilustrasikan sebagai berikut: 
Gambar 2. Model Pengembangan Kurikulum UIN Maulana Malik Ibrahim Malang dan Universitas Islam Malang

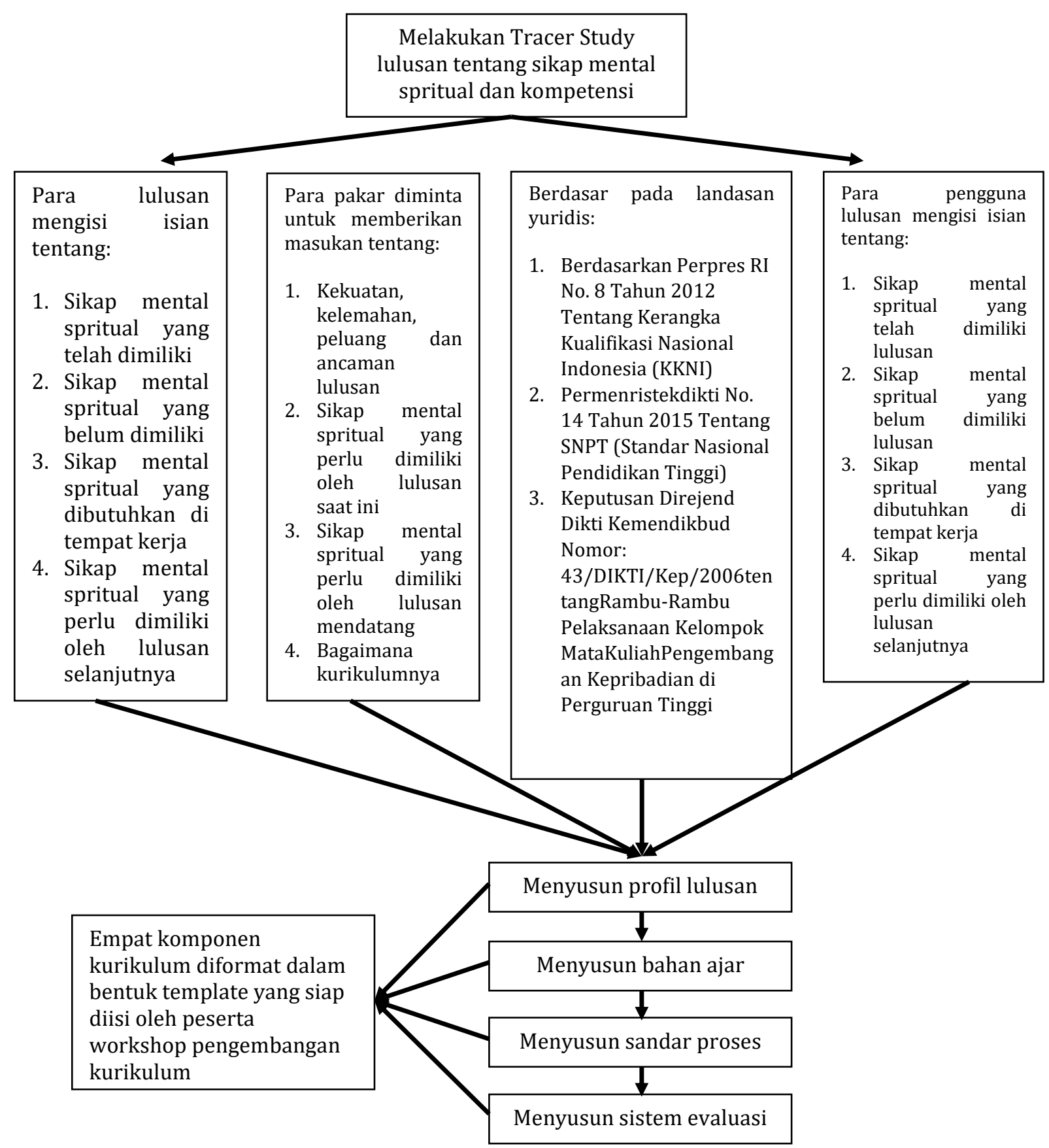

\section{Kesimpulan}

Ternyata apa yang selama ini diyakini bahwa perguruan tinggi dalam menyusun kurikulum hanya sekedarnya, dan berangkat dari dokumen kurikulum sebelumnya, tanpa melihat fakta tentang lulusan adalah tidak benar adanya. Berdasar studi ini, setidaknya di dua perguruan tinggi dimaksud telah menyusun kurikulumnya dengan langkah awal mengidentifikasi performance lulusan dan tanggapan pengguna lulusan terlebih dahulu. Hal ini penting untuk meningkatkan asas kebermanfaatan perguruan tinggi kepada masyarakat. Dan adanya tanggung jawab berkelanjutan perguruan tingginya kepada lulusannya.

Sebagaimana ditulis sebelumnya, bahwa tujuan utama penelitian ini untuk menemukan sebuah model ideal pengembangan kurikulum Mata Kuliah Pengembangan 
Mohammad Karim: Model Pengembangan Kurikulum...

Kepribadian (MPK), maka konsep yang ditawarkan penelitian ini sebagai sebuah temuan dapat menjadi contoh ideal bagi para penanggung jawab perguruan tinggi khususnya, dan umumnya bagi lembaga pendidikan baik perguruan tinggi maupun sekolah dalam rangka proses pengembangan kurikulum pendidikan karakter. Bukankah pendidikan karakter menemukan kembali semangatnya akhir-akhir ini.

\section{DAFTAR PUSTAKA}

Aqil, S. (2019, Okt). Pidato Kebangsaan. Www.Nuonline.Com. Retrieved from https://www.youtube.com/watch?v=7028KK1kCOk

Arifn, z. (2012). Konsep dan Model Pengembangan Kurikulum. Bandung: PT remaja rosdakarya.

Arsanti. (2018). Pengembangan Bahan Ajar Mata Kuliah Penulisan Kreatif Bermuatan Nilai-Nilai Pendidikan Karakter Religius Bagi Mahasiswa Prodi Pbsi, Fkip, Unissula. Jurnal Kredo, Vol. 1 No. 2, 3.

Belladonna, A. P. (2013). Pendidikan Kewarganegaraan Sebagai Wahana Dalam Meningkatkan Kesadaran Hukum Mahasiswa: Studi Kasus di STKIP Pasundan Cimahi. (Universitas Pendidikan Indonesia). Universitas Pendidikan Indonesia. Retrieved from http://repository.upi.edu/8355/

Bidshahri, R. (2017). Critical Skills for the Jobs of the Future. Singularity Hub. (Query date: 2020-1028 12:11:37).

Dahlan, D., Budiwat, \& Kurniawati. (2013). Pengembangan Model Kurikulum Pendidikan Ekonomi Untuk Menyiapkan Guru Profesional Di Sekolah Bertaraf Internasional. Jurnal Pendidikan Ekonomi Dan Bisnis (JPEB) Vol.1 No.2 Oktober 2013. Retrieved from http://www.jpeb.net

Damayanti, Nurhayati, \& Subadiyono. (2018). Pengembangan Modul Mata Kuliah Pengembangan Kepribadian (MPK) Bahasa Indonesia Pada Program Studi Ilmu Komunikasi Fakultas Ilmu Sosial Dan Ilmu Politik Universitas Baturaja. Retrieved from http://ejournal.fkip.unsri.ac.id/index.php/logat/article/view/54

Detik.com. (2019, January 10). Ironi-dosen-malah-jadi-penyebar-hoax-bom-surabaya-pengalihanisu. Detik.Com. Retrieved from https://news.detik.com/berita/d-4378263/ironi-dosenmalah-jadi-penyebar-hoax-bom-surabaya-pengalihan-isu

Fajaryati, Priyanto, Sukardiyono, Utami, Pambudi, \& Destiana. (2015). Studi Penelusuran(Tracer Study) Terhadapalumniprogram Studipendidikan Teknik Informatika Jurusan Pendidikan Teknik Elektronikafakultas Teknik Universitas Negeri Yogyakarta. Jurnal Electronics, Informatics, and Vocational Education (ELINVO), Volume 1, Nomor 1, November 2015, 1, 1.

Firmansyah. (2020). Pengembangan Kurikulum Pendidikan Agama Islam Berbasis Multikultural. 165.

Gu, J., Zhang, Y., \& Liu, H. (2014). Importance of social capital to student creativity within higher education in China. Thinking Skills and Creativity. https://doi.org/10.1016/j.tsc.2013.12.001

Hakim, Tobroni, Ishomuddin, \& Khozin. (2020). Pendidikan Islam Integratif: Best Practice Integrasi Pendidikan Agama Islam dalm Kurikulum Pendidikan TInggi. Surabaya: Gestalt Media. Retrieved from

Sen malah jadi penyebar hoax bom surabaya pengalihan isu. (2019, January 10). Detik.Com. Retrieved from https://news.detik.com/berita/d-4378263/ironi-dosen-malah-jadipenyebar-hoax-bom-surabaya-pengalihan-isu.

kbbi.kemdikbud.go.id. (2020). Distribusi. Retrieved from https://kbbi.kemdikbud.go.id/entri/

kbbi.kemdikbud.go.id. (2020). Mencetak. Retrieved from https://kbbi.kemdikbud.go.id/entri/mencetak

kbbi.kemdikbud.go.id. (2020). Mengunggah. $\quad$ Retrieved from https://kbbi.kemdikbud.go.id/entri/Mengunggah

kbbi.kemdikbud.go.id. (2020). Pengesahan. Retrieved https://kbbi.kemdikbud.go.id/entri/pengesahan

kbbi.kemdikbud.go.id. (2020). Presentasi. $\quad$ Retrieved from https://kbbi.kemdikbud.go.id/entri/presentasi 
kbbi.kemdikbud.go.id. (2020). Revisi. In Https://kbbi.kemdikbud.go.id/entri/revisi. Retrieved from https://kbbi.kemdikbud.go.id/entri/revisi

Kelley, T., Knowles, J., Han, J., \& ... (2019). Creating a 21st Century Skills Survey Instrument for High School Students. American ..., (Query date: 2020-10-26 20:32:24). Retrieved from http://article.scieducationalresearch.com/pdf/education-7-8-7.pdf

liputan6.com. (2019, January 7). Nasib-oknum-mahasiswa-penyebar-hoaks-di-gorontalo. Liputan6.Com. Retrieved from https://www.liputan6.com/regional/read/3872758

Maimun, A. (2016). Pengembangan Silabus.

Mukhibat. (2020). Reinventing nilai-nilai islam, budaya, dan pancasila dalam pengembangan Pendidikan Karakter. Fakultas Tarbiyah Dan Keguruan UIN Sunan Kalijaga Yogyakarta Bekerja Sama Dengan Himpunan Sarjana Pendidikan Islam (HiSPI). Retrieved from http://ejournal.uin-suka.ac.id/tarbiyah/index.php/JPI/article/view/1123/1019

news.detik.com. (2019, January 12). Miris-penyebar-hoax-dulu-dosen-kini-guru. Detik.Com. Retrieved from https://news.detik.com/berita/d-4381331/miris-penyebar-hoax-duludosen-kini-guru

Puncreobutr, V. (2016). Education 4.0: New challenge of learning. St. Theresa Journal of Humanities and Social Sciences, (Query date: 2020-10-26 20:32:24). Retrieved from http://www.stic.ac.th/ojs/index.php/sjhs/article/view/Position\%20Paper3

Republika.com. (2017). Ada 800000 situs penyebar hoax di indonesia. Republika.co.id. Retrieved from https://www.republika.co.id/berita/nasional/umum/17/12/12/p0uuby257

Riyanto, A. (2009, 2020). Model Penyelenggaraan Mata Kuliah Umum Di Universitas Pendidikan Indonesia, makalah Disajikan dalam Lokakarya dan Forum Diskusi Nasional Mata Kuliah Pengembangan Kepribadian: Pengukuhan Jati Diri dan Integritas Bangsa dalam Membangun Wawasan Nasional Memasuki Reformasi Gelombang Kedua Menuju Visi Indonesia 2025. Presented at the Bandung. Bandung.

Sanjaya W. (2008). Kurikulum dan Pembelaran. Jakarta: Kencana Prenada Media Group.

SIDIK, I., AWANG, M., \& AHMAD, A. (2019). The Relationship between Students' Involvement in 21st Century Classroom Learning Activities and Higher Order Thinking Skills (Hubungan antara Keterlibatan .... Jurnal Pendidikan Malaysia ..., (Query date: 2020-10-26 20:32:24). Retrieved from http://ejournal.ukm.my/jpend/article/view/44.01-07

Silaen, D. (2020, July 9). Layout Design. Retrieved from https://medium.com/@desriyanisilaen/layout-design-fae5cd60a36,

Solehah, 1. Mardiatus, Rafi Fatkhi, 2. Muhamad, \& Dhiyah, $3 . \quad$ Nada. (2020, Agustus). Model Pengembangan Kurikulum. Retrieved from https://www.academia.edu/30581093/Makalah_Model_Pengembangan_Kurikulum

Sugihartono, B. (2013, July). Kuliah Filsafat dengan tema Humanisme dan Humaniora. Retrieved from https://www.youtube.com/watch?v=rKvrqhyrsHY

Sunarto, \& Suhardiyanto. (2013). Aktualisasi Pendidikan Karakter Dalam Proses Pembelajaran Mata Kuliah Umum (MKU) Di Universitas Negeri Semarang. Jurnal Penelitian Pendidikan Vol. 30 Nomor 1 Tahun 2013. https://doi.org/10.15294/jpp.v30i1.5668

Syarif, M. (2017). The model of implementing character-based holistic education in learning. International Journal of Economic Research, 14(12), 381-390.

tirto.id. (2019, January 14). Masalah-orangtua-gemar-membagi-hoaks-di-medsos-dan-whatsapp. Retrieved from https://tirto.id/masalah-orangtua-gemar-membagi-hoaks-di-medsos-danwhatsapp-decZ

Trim, B. (2017). 200+ Solusi Editing Naskah dan Penerbitan. Jakarta: Bumi Aksara.

Widya. (2020). Validity and practicality of integrated science teaching materials based on Creative Problem Solving model as an efforts for the establishment of anticorruption characters. Journal of Physics: Conference Series, 1481(1). https://doi.org/10.1088/17426596/1481/1/012079

Zulkifli, R., Hussain, M., Wahid, N. A., \& ... (2019). Implementation of the 21st century learning approach among technical and vocational education trainee teachers. ... 4.0: Proceedings of ..., (Query date: 2020-10-26 20:32:24). 